\title{
Effect of Calf Gender on Milk Composition, Reproductive Hormones and Serum Biochemical Parameters of Female Dromedary Camel
}

\author{
Asem Mohammed Zakaria ${ }^{1}$ and Ragab Hassan Mohamed $^{2}$ \\ ${ }^{1}$ Department of Food Hygiene, Faculty of Veterinary Medicine, Aswan University, Egypt \\ ${ }^{2}$ Department of Theriogenology, Faculty of Veterinary Medicine, Aswan University, Egypt \\ *Corresponding author: asemzakaria@yahoo.com
}

\begin{abstract}
\begin{tabular}{llll}
\hline Article History: 20-121 & Received: 17-May-20 & Revised: $30-A u g-20$ & Accepted: 06-Sep-20
\end{tabular}
\section{ABSTRACT}

Arabian dromedary camels received little interest compared to other domestic animals. Literature data about factors affecting camel's milk composition and serum biochemical profile are limited and not sufficient. In the present study a total of 60 milk samples (Three milk samples were collected from each animal for three consecutive days) and 20 blood samples were collected individually from 20 clinically healthy female dromedary camels at first month of lactation to study the effect of calf gender on milk composition, some hormonal and serum biochemical profile. Animals were grouped into two groups, A and B. Group A contained 10 females dromedary camels that gave birth to male calves and Group B contained 10 females dromedary camels that gave birth to female calves. All samples were analyzed, and the result revealed that calf gender has non-significant effect $(\mathrm{P}>0.05)$ on milk composition, serum progesterone, cortisol, calcium and magnesium levels. While significant effect but not sharp $(\mathrm{P}=0.02)$ were observed on serum phosphorus levels and high significant effect were recorded on serum estrogen level $(\mathrm{P}<0.0001)$.Since such study are rare inEgypt, the data presented, could be used as a reference guide for the effect of calf gender on milk composition, reproductive hormones and serum biochemical parameters of female dromedary camel during early lactation.
\end{abstract}

Key words: Calf gender, Milk composition, Reproductive hormones, Biochemical parameters, Dromedary camel.

C2020 IJVS - All Rights Reserved

\section{INTRODUCTION}

Dromedary camels are considered the fifth most important dairy animals around the world after cattle, buffalo, sheep and goat, but for dissert people camel considered as the first important dairy animal because of its importance as a source of milk, meat and mean of transportation (Mohamed et al. 2019; Chemweno et al. 2019). In arid zones in Africa and Asia camel can produce more milk under harshly environment for a longer period than any other dairy animals (Kula and Tegegne, 2016). Camel milk differs from other ruminant milk as it contains high minerals (iron, potassium, sodium, zinc, magnesium and copper), low sugar, high protective proteins (lactoferrin, lysozyme, lactoperoxidase, immunoglobulins), low cholesterol and high vitamin C (Yadav et al. 2015). Also, camel milk has been used since ancient times as a medicine for treatment of many diseases such as asthma, jaundice, anti-hypertensive, dropsy and leishmaniasis (Gader et al. 2016). Despite all these advantages present in Arabian dromedary camels, it received little interest compared to other domestic animals
(Ebissy et al. 2019). By increasing awareness about the nutritional facts and health benefits of camel's milk and using camel for racing, more attention was given to study various factors affecting its physiological stat and reproductive performance (Nagy et al. 2017). Dromedary camels are seasonal breeders and induced ovulators Pregnancy and parturition in she camel are dynamic processes which characterized by many physiological changes that may affect biochemical values and hormonal levels in blood (Abd-El-Rahman et al. 2017). There are many factors affecting milk yield, composition, serum biochemical profile and reproductive hormones of female dromedary camel, this factor can be classified into inherited and non-inherited factors. Non inherited factors can be further grouped into internal factors as (pregnancy status, lactation number, age etc) and external factors as (humidity, temperature, feeding, etc). Calf gender is considered as non-inherited, internal factor (Chegini et al. 2019). Sexed semen can determine the calf gender, so if the calf gender has significant effect on milk composition, we can use sexed semen technique to improve camel milk quality.

Cite This Article as: Zakaria AM and Mohamed RH, 2021. Effect of calf gender on milk composition, reproductive hormones and serum biochemical parameters of female dromedary camel. International Journal of Veterinary Science 10(1): 47-50. https://doi.org/10.47278/journal.ijvs/2020.004 
In the present study we aimed to monitor the effect of calf gender on milk composition, reproductive hormones and serum biochemical parameters of female dromedary camel during early lactation under Egyptian condition.

\section{MATERIALS AND METHODS}

Animals: Twenty apparently healthy lactating female dromedary camels, reared at camel's farm in Matrouh province Egypt, having 500-550kg live body weight, and 6-7 years old. All animals normally calved throughout the period from December 2019 to March 2020. The camels were considered clinically healthy depending on physical examination of heart, lungs, rumen and intestine. Clinical examination was done according to (Radostitis et al. 2007). Animals were grouped into two groups (A and B).

Group A: 10 females dromedary camels nursing male calves. Group B: 10 females dromedary camels nursing female calves.

Feeding system: all animals receiving the same diet which contain $2.5-3 \mathrm{~kg}$ rice straw, $3.5-4.4 \mathrm{~kg}$ concentrate feeding mixture and $2.5-3 \mathrm{~kg}$ berseem hay. Water was offered all the time.

Blood sampling: $10 \mathrm{ml}$ blood samples were collected via jugular vein puncture without anticoagulant from each animal using vacutainer. Plain tubes were centrifuged at $3000 \mathrm{rpm}$ for 15 minutes to obtain clear serum. Samples were kept frozen for Subsequent biochemical analyses at $20^{\circ} \mathrm{C}$. For the phosphorus, calcium, magnesium, commercial test kits used were Ref: PH123100, CAL103100 and MG122050 respectively from Bio Med Egypt. Test kits used for cortisol and estradiol, were Ref: KGE008B, and KGE014 respectively supplied by Parameter TM USA. Commercial test kit used for Progesterone, was (Ref: EA 74) supplied by Oxford Biomedical Research USA. The test kits were used in accordance with the standard protocol of their manufacture.

Milk Sampling: A total of 60 milk samples (500 ml each) were collected individually from 20 hand milked female dromedary camels (Three samples were collected from each animal for three consecutive days) in screw-capped bottles and kept frozen tell be examined. All samples were examined at Animal Health Research Institute laboratories, Doki, Giza, Egypt. Milk constituents as protein, fat, carbohydrates, ash, lactose and moisture were examined by Lactoscan SL (manufactured by Milkotronic Ltd, Bulgaria) according to (Chappalwar et al. 2014). Milk mineral contents as calcium $(\mathrm{Ca})$, sodium $(\mathrm{Na})$, magnesium $(\mathrm{Mg})$, potassium $(\mathrm{K})$, zinc $(\mathrm{Zn})$, chloride $(\mathrm{Cl})$ and copper $(\mathrm{Cu})$ were measured according to (AOAC, 1980) using atomic absorption, Unicam 929. Phosphorous was measured colorimetrically in the ash according to (AOAC 1980).

Statistical analysis: Data were entered as categorical or numerical and were analyzed using SPSS program version 20 (SPSS Inc, Chicago, Illinois, USA). Quantitative data were presented as mean \pm SE.

\section{RESULTS}

In the present study a total of 60 milk samples and 20 blood samples were collected from 20 clinically healthy female's dromedary camels at first month of lactation to study the effect of calf gender on milk composition, some hormones and serum biochemical profile. Animals were grouped into two groups, Group A which contain 10 females dromedary camels that gave birth to male calves and Group B which contain 10 females dromedary camels that gave birth to female calves. All samples were analyzed and the result recorded in Tables 1 and 2 revealed that calf gender has no significant effect on chemical milk constituents as Protein, Fat, Lactose, SNF, T.S, Moisture and minerals, also data recorded in Table 3 pointed out that calf gender has no significant effect on serum biochemical parameters as Cortisol, Progesterone, $\mathrm{Ca}$ and $\mathrm{Mg}$ levels but have significant effect on Estrogen (E2) and phosphorus.

Table 1: Effect of calf gender on milk composition (mean \pm SE) of dromedary camel

\begin{tabular}{lrrc}
\hline Milk constituents (\%) & \multicolumn{1}{c}{ Group A } & \multicolumn{1}{c}{ Group B } & P value \\
\hline Protein & $3.74 \pm 0.21$ & $3.66 \pm 0.32$ & 0.835 \\
Fat & $4.14 \pm 0.18$ & $3.96 \pm 0.16$ & 0.457 \\
Ash & $0.75 \pm 0.06$ & $0.71 \pm 0.03$ & 0.553 \\
Lactose & $4.02 \pm 0.24$ & $4.57 \pm 0.19$ & 0.077 \\
SNF & $8.60 \pm 0.27$ & $8.97 \pm 0.19$ & 0.267 \\
Total Solids & $12.79 \pm 0.20$ & $12.92 \pm 0.18$ & 0.630 \\
Moisture & $87.20 \pm 0.13$ & $86.97 \pm 0.16$ & 0.269 \\
\hline
\end{tabular}

Table 2: Effect of calf gender on mineral contents (mean $\pm \mathrm{SE}$ ) of camel milk (mg/100g)

\begin{tabular}{lccc}
\hline Minerals & Group A & Group B & P value \\
\hline $\mathrm{Na}$ & $59.82 \pm 0.36$ & $60.2 \pm 0.26$ & 0.395 \\
$\mathrm{~K}$ & $159.43 \pm 1.21$ & $156.27 \pm 1.35$ & 0.086 \\
$\mathrm{Mg}$ & $6.97 \pm 0.23$ & $6.38 \pm 0.15$ & 0.035 \\
$\mathrm{Cu}$ & $0.05 \pm 0.004$ & $0.05 \pm 0.003$ & 1 \\
$\mathrm{CL}$ & $119.12 \pm 0.11$ & $118.63 \pm 0.12$ & 0.06 \\
$\mathrm{Ca}$ & $119.75 \pm 2.33$ & $120.04 \pm 1.8$ & 0.921 \\
$\mathrm{P}$ & $79.63 \pm 1.70$ & $80.22 \pm 1.5$ & 0.795 \\
$\mathrm{Ca} / \mathrm{P}$ & $1.50 \pm 1.37$ & $1.49 \pm 1.2$ & 0.995 \\
\hline
\end{tabular}

Table 3: Effect of calf gender on some reproductive hormones and serum biochemical profile (mean \pm SE) of female camel

\begin{tabular}{lccc}
\hline Parameters & Group A & Group B & P value \\
\hline Cortisol $(\mu \mathrm{g} / \mathrm{dl})$ & $1.41 \pm 0.34$ & $1.55 \pm 0.19$ & 0.51 \\
Progesterone $(\mathrm{ng} / \mathrm{ml})$ & $0.73 \pm 0.06$ & $0.87 \pm 0.04$ & 0.743 \\
Estrogen $(\mathrm{pg} / \mathrm{ml})$ & $74 \pm 2.51$ & $131.3 \pm 1.85$ & $<0.0001$ \\
Calcium $(\mathrm{mmol} / \mathrm{l})$ & $2.16 \pm 0.02$ & $2.33 \pm 0.08$ & 0.186 \\
Phosphorous $(\mathrm{mmol} / \mathrm{l})$ & $1.51 \pm 0.008$ & $1.84 \pm 0.05$ & 0.023 \\
Magnesium $(\mathrm{mmol} / \mathrm{l})$ & $1.22 \pm 0.015$ & $1.20 \pm 0.015$ & 0.407 \\
\hline
\end{tabular}

Group A: 10 females dromedary camels nursing male calves; Group B: 10 females dromedary camels nursing female calves.

\section{DISCUSSION}

The composition of Egyptian dromedary camel milk was described in many previous studies and has been summarized by many researchers (Ahmed et al. 2014; Khalifa and Zakaria, 2019; Mohamed et al. 2019). But literature data about factors affecting camel's milk composition and serum biochemical profile are limited and not sufficient. There are many factors affecting milk composition, the most major factors are, stage of lactation, breed, parity, management or production system (Aljumaah et al. 2012), season (Shuiep et al. 2008), feeding (Al-Saiady et al. 2012), geographical location, and year (Konuspayeva et al. 2009). There are very little researches on the effect of calf gender on milk composition (Nagy et al. 2017). So in the present study, effect of calf gender on 
milk composition were studied and the results reported in Table 1showed that there's no significant effect of calf gender on chemical composition of camel's milk $(\mathrm{P}>0.05)$. Nearly similar result were recorded by Nagy et al. (2017) who reported that calf gender has no significant effect on camel milk protein, fat and TS concentrations by contrast he reported that calf gender has significant effect on lactose and SNF concentrations which higher in milk from dams with female calves than in milk from dams with male calves $(\mathrm{P}<0.05)$. With reference to other species Hamad and Moghazy (2015) reported that sex of birth had no significant effect on milk composition of Egyptian Buffalo's.

Inspection of Table 2pointed out that calf gender has no significant effect on milk minerals contents of both groups (A and B). Although the difference is not significant, but there's little increase in $\mathrm{Ca}$ and $\mathrm{P}$ contents in milk for female calves, this increase may to compensate the reduction in milk production (Hamad and Moghazy 2015) as dromedary camels nursing a male calf produce more milk than do dromedary camels nursing a female calf (Nagy et al. 2017). K and Mg showed the opposite sex effects in contents as little increase in $\mathrm{K}$ and $\mathrm{Mg}$ contents for dromedary camels nursing a male calf than dromedary camels nursing a female calf. The cause of higher $\mathrm{Mg}$ content in milk for males may be due to the role of $\mathrm{Mg}$ in bone formation as $\mathrm{Mg}$ can substitute $\mathrm{Ca}$ in bone (Ergun et al. 2002). Similarly, K plays an important role in bone formation (Landete-Castillejos et al. 2007). Greater K intake helps to reduce $\mathrm{Ca}$ losses in urine and thus promote its accretion in the bone (Cashman 2006). In Iberian deer, Gallego et al. (2009) reported that milk of female nursing male calf had greater contents of $\mathrm{Mg}$ and $\mathrm{K}$ but lower contents of $\mathrm{P}$ and $\mathrm{Ca}$, whereas no sex effects on $\mathrm{Fe}, \mathrm{Na}$, or $\mathrm{Zn}$.

Studying factors affecting serum biochemical profile is very important for assessing the health status and physiological condition of the animal. These factors can be classified in to genetic and non-genetic factors which have direct and in-direct effects on serum biochemical profile and blood electrolytes and subsequently on the production and health performances of the animals (Onasanya et al. 2015). Blood electrolytes are involved in all living processes as they play an important role in maintaining homeostasis, regulating most metabolic processes, involved in the capacity of structural elements and very important for milk production (Mohamed et al. 2019). Regarding the calf gender as a non-genetic factor affecting blood electrolytes, data recorded in Table 3 pointed out that calf gender have no significant effect on serum calcium and magnesium levels $(\mathrm{P}>0.05)$, while significant effect but not sharp were observed on phosphorus $(\mathrm{P}=0.023)$. Blood concentration of phosphorus, calcium, and magnesium are usually linked as they have the same homeostatic mechanisms. During disease, the concentration of magnesium increases while calcium and phosphorus concentrations in the blood decrease (Hadzimusia and Kranic 2012).

The pattern of secretion of reproductive hormones has been reported in sheep, goat, mare, buffalo, cattle and pig but Literatures are scanty and less well understood in the camel. Female dromedary camels' reproduction is characterized by a seasonal activity, induced ovulation and exhibits follicular cycles with follicles developing and regressing successively (Mohamed et al. 2019). Analysis of reproductive hormones during early lactation can aid in the diagnosis of ovarian structures status, some pathological infertility problems and improving fertility in subsequent pregnancies. level of reproductive hormones in blood may be affected by many parameters as age, species, breed, malnutrition, illness, season, reproductive status, management systems and nutrition (Swanson et al. 2004). In the present study, effect of calf gender on some reproductive hormones were reported in table 3 and the result revealed that calf gender have no significant effect on progesterone and cortisol level, but high significant effect on estrogen level were observed $(\mathrm{P}<0.05)$. The maternal estradiol is fetoplacental in origin, and its level dropped following parturition (Abd-El-Rahman et al. 2017). Estradiol improve uterine clearance and involution by stimulation of my ometrium and endometrium activity (Sheldon et al. 2003). In the previous studies (El-Naggar 2012; Gad et al. 2017) reported that calf gender has great influence on uterine parameters (uterine lumen diameter, cranial and ventral uterine curvature) and uterine involution, also they found that buffalo cows nursing female calves have short time for uterine involution and dams have bull calves returned to estrus and uterine involution more slowly. Consequently, this may be an explanation for the significant increase of estrogen level in female dromedary camel nursing female calve than that nursing male calve.

Progesterone level is a very useful tool to determine pregnancy in she camels (Alfuraiji et al. 1998). Corpus luteum considered as the primary source of progesterone in the female dromedary camel. The placenta has no role in progesterone secretion (Skidmore 2005). Cortisol is the hormone which used as an indicator of stress in animals, it can predict the time of parturition in female dromedary camel (Skidmore 2005). Blood cortisol level gradually increased during pregnancy specially at the third trimester and reach maximum level on the day of parturition then its level markedly decreased after parturition. Cortisol level increased after transportation and in case of hypoxemia but not affected by food deprivation specially in dromedary camel. The three hormones, cortisol, estradiol and progesterone can be used as indicators to predict the parturition time in female dromedary camel (Abd-ElRahman et al. 2017).

\section{Conclusion}

Calf gender has no significant effect on milk composition, serum progesterone, cortisol, calcium and magnesium levels, significant effect but not sharp on serum phosphorus level and has high significant effect on serum estrogen level. More studies on larger number of animals under different conditions are required to well understood the effect of calf gender on milk composition and serum biochemical profile of female dromedary camel under Egyptian condition.

\section{REFERENCES}

Abd-El-Rahman HMA, Ibrahim MA and Elmetwaly HA, 2017. Hormonal profile, antioxidant status and some biochemical parameters during pregnancy and periparturient period in 
dromedary she camel Egypt. Journal of Veterinary Science 48: 81-94. https://doi.org/10.21608/EJVS.2017.2040.1022

Ahmed AAH, Sayed RG, and Sayed M, 2014. Nutritional value and sanitary evaluation of raw camel's milk. Emirates Journal of Food and Agriculture 26: 317-326.

Alfuraiji MM, 1998. Concentrations of plasma oestradiol-17 $\beta$, progesterone and cortisol in pre-and postpartum stages of Arabian she-camel. Arab Gulf Journal of Scientific Research 16: 173-182.

Aljumaah RS, Almutairi FF, Ismail E, Alshaikh MA, Sami A and Ayadi M, 2012. Effects of production system, breed, parity and stage of lactation on milk composition of dromedary camels in Saudi Arabia. Journal of Animal and Veterinary Advances 11: 141-147.

Al-Saiady MY, Mogawer HH, Faye B, Al-Mutairi SE, Bengoumi M, Musaad A and Gar-Elnaby A, 2012. Some factors affecting dairy she-camel performance. Emirates Journal of Food and Agriculture 24: 85-91.

AOAC, 1980, Official Methods of Analysis. $13^{\text {th }}$ Ed. Association of Official Analytical Chemists, Washington, DC.

Cashman KD, 2006. Milk minerals (including trace elements) and bone health. International Dairy Journal 16: 1389-1398.

Chappalwar AM, Devangare AA, Kodamlwar NK and Sahu RK, 2014. Detection of extraneous water adulteration and physicochemical quality of market milk collected from different areas of Parbhani. Research Journal of Animal Husbandry and Dairy Science 5: 109-112.

Chegini A, Shadparvar AA, Hossein-Zadeh NG and MohammadNazari B, 2019. Genetic and environmental relationships among milk yield, persistency of milk yield, somatic cell count and calving interval in Holstein cows. Revista Colombiana de Ciencias Pecuarias 32: 81-89.

Chemweno VJ, Gitao CG, Gachohi JM, Soi RK, Ndungu EK, Khalif A and Omani RN, 2019. PPR in Camels: Seroprevalence and socio-economics. International Journal of Veterinary Science 8: 84-88.

Ebissy E, El-Sayed A and Mohamed R, 2019. Hematological and biochemical profile in female camels (Camelus Dromedarius) during the transition period. Slovenian Veterinary Research 56 (Suppl 22): 571-577.

El-Naggar RAM, 2012. the relation between reproductive performance and milk constituents in buffalo-cows. PhD Thesis, Faculty of Veterinary Medicine, Benha University, Egypt.

Ergun C, Webster TJ, Bizios R and Doremus RH, 2002. Hydroxylapatite with substituted magnesium, zinc, cadmium, and yttrium. I. Structure and microstructure. Journal of Biomedical Materials Research 59: 305-311.

Gad BA, Mohamed MM, El-Azab AI, Sosa GA and Essawy SA. 2017. Ultrasonographic monitoring of uterine involution in postpartum buffalo cows. Journal of Advanced Veterinary Research 7: 93-99.

Gader AGM and Alhaider AA, 2016. Theunique medicinal properties of camelproducts: A review of the scientific evidence. Journal of Taibah University Medical Sciences 11: 98-103.

Gallego L, Gomez JA, Landete-Castillejos T, Garcia AJ, Estevez JA, Ceacero F and de la Cruz L F. 2009. Effect of milk minerals on calf gains and sex differences in mineral composition of milk from Iberian red deer (Cervus elaphushispanicus). Reproduction 138: 859-865.
Hadzimusia N and Kranic J, 2012. Values of calcium, phosphorus and magnesium concentrations in blood plasma of cows in dependence on the reproductive cycle and season. Journal of Faculty of Veterinary Medicine, Istanbul University 38: 1-8.

Hamad MNF and El-Moghazy MM, 2015. Influence of sex and calf weight on milk yield and some chemical composition in the Egyptian buffalo's. Journal of Animal and Veterinary Sciences 2: 22-27.

Khalifa, MI and Zakaria AM, 2019. Physiochemical, sensory characteristics and acceptability of a new set yogurt developed from camel and goat milk mixed with buffalo milk. Advanced Animals and Veterinary Science 7: 172-177. http://doi.org/10.17582/journal.aavs/2019/7.3.172.177

Konuspayeva G, Faye B and Loiseau G, 2009. The composition of camel milk: A meta-analysis of the literature data. Journal of Food Composition and Analysis 22: 95-101.

Kula JT and Tegegne D, 2016. Chemical composition and medicinal values of camel milk. International Journal of Research Studies in Biosciences 4: 13-25.

Landete-Castillejos T, Garcia A and Gallego L, 2007. Body weight, early growth and antler size influence antler bone mineral composition of Iberian red deer (Cervus elaphushispanicus). Bone journal 40: 230-235.

Mohamed RH, Zakaria AM, Keshta HG and Ghallab RS. 2019 Milk composition, ovarian hormones and serum biochemical profile of apparently healthy female dromedary camels during early lactation. Journal of Bioscience Research 16(S1-2): 15-21.

Nagy P, Fábri ZN, Varga L, Reiczigel J and Juhász J. 2017. Effect of genetic and nongenetic factors on chemical composition of individual milk samples from dromedary camels (Camelus dromedarius) under intensive management. Journal of Dairy Science 100: 8680-8693. https://doi.org/10.3168/jds.2017-12814

Onasanya GO, Oke FO, Sanni TM and Muhammad AI, 2015. Parameters influencing haematological, serum and biochemical references in livestock animals under different management systems. Open Journal of Veterinary Medicine 5: 181 .

Radostitis O M, Gay CC; Hinchcliff KW and Constable PD, 2007. Veterinary Medicine, 10th Ed. W. B. Saunders Company Ltd, London, UK.

Sheldon, IM, Noakes DE, Rycroft AN and Dobson H, 2003. The effect of intrauterine administration of estradiol on postpartum uterine involution in cattle. Theriogenology 59: 1357-1371. https://doi.org/10.1016/S0093-691X(02)01169X

Shuiep, ES, El Zubeir IEM, El Owni OAO and Musa HH, 2008 Influence of season and management on composition of raw camel (Camelus dromedarius) milk in Khartoum state, Sudan. Tropical and Subtropical Agroecosystems 8: 101106.

Skidmore JA, 2005. Reproduction in dromedary camels: an update. Journal of Animal Reproduction 2: 161-171.

Swanson KS, Kuzmuk KN, Schook LB and Fahey JGC, 2004. Diet affects nutrient digestibility, hematology, and serum chemistry of senior and weanling dogs. Journal of Animal Science 82: 1713-1724.

Yadav AK, Kumar R, Priyadarshini L and Singh J, 2015. Composition and medicinal properties of camel milk: A Review. Asian Journal of Dairy and Food Research 34: 8391. https://doi.org/10.5958/0976-0563.2015.00018.4 